\title{
ОНОМАСТИЧНІ ШКОЛИ В УКРАЇНІ
}

\author{
ДОМІНІКА ЯНЧУРА \\ Університет імені Адама Міцкевича, Познань - Польща \\ dominikajanczura@interia.eu \\ OŚRODKI ONOMASTYCZNE NA UKRAINIE \\ DOMINIKA JANCZURA \\ Uniwersytet imienia Adama Mickiewicza, Poznań — Polska
}

STRESZCZENIE. W artykule opisano powstanie i etapy rozwoju ukraińskiej onomastyki. Wymieniono główne ośrodki onomastyczne aktywnie działające na Ukrainie. Scharakteryzowano kierunki działań ich przedstawicieli. Określono niespójności dotyczące terminologii oraz systematyzacji nazw własnych, występujące w danych ośrodkach onomastycznych.

\section{ONOMASTIC SCHOOLS IN UKRAINE}

DOMINIKA JANCZURA

Adam Mickiewicz University, Poznan — Poland

ABSTRACT. The creation and stages of the progress of Ukrainian onomastics have been described in the article. It has been mentioned the major onomastic centers, which are active in Ukraine. It has been characterized the directions of the action of their representatives. As a result the article defines the inconsistencies related to the terminology and systematization of the proper names, occurring in the onomastic centers.

$\mathrm{Y}$

всіх мовах світу розрізняють дві лексичні групи - апелятивну, що об'єднує загальні назви, й онімну (пропріальну), що охоплює власні назви ${ }^{1}$. Ю. Карпенко зауважує, що „кожна мова має мільйони, якщо не десятки мільйонів власних назв, які містять величезну інформацію і мають значне мовне навантаження"”. Особливістю, що відрізняє оніми від загальних назв, $€$ те, що вони називають окремі одиничні об'єкти. С. Вербич пояснює, що „загальні назви об'єднують певні однорідні об'єкти, узагальнюють їх, а власні, навпаки, їх диференціюють"з.

Наголосимо, що власні назви прямо чи опосередковано утворені від загальних назв і $є$, отже, відносно них вторинними ${ }^{4}$. Ю. Карпенко уточнює, що це не означає, що спочатку виникли загальні назви, а вже потім власні - розмежування цих двох груп не існувало, поки в мові не виділилася група власних назв 5 , тобто були слова, що згодом поділилися на загальні та власні. В. Лучик зауважує, що „особливість пропріальної лексики полягає насамперед у ії специфічній семантиці, зумовленій диференційно-індивідуалізуючою функцією власних

1 С. Вер бич, Сучасна украйнська онімна лексика: функціональний аспект, [в:] „Вісник НАНУ” 2008, № 5, с. 54.

${ }^{2}$ Ю. О. Карпенко, Ономастичні міркування, [в:] „Записки з ономастики”, зб. наук. праць, відп. ред. Ю.О. Карп ен ко, Одес. нац. ун-т ім. І. І. Мечникова, Одеса 2005, вип. 9, с. 17.

${ }^{3} \mathrm{C}$. Верб ич, зазнач. джер., с. 54.

${ }^{4}$ Ю. О. Карпенко, зазнач. джер., с. 11.

${ }^{5}$ Там само. 
назв”. Цей дослідник зазначає, що „як і в системі загальних назв, у пропріальній лексиці з найдавніших часів був і залишатиметься важливим на далеку перспективу напрям описової лінгвістики, пов'язаний з фіксацією, систематизацією, інтерпретацією будови, значення, функцій і т. ін. онімів"”. А Ю. Карпенко переконаний, що „специфіка власних назв та їхні відмінності від назв загальних настільки істотні, що онімічні дослідження виділилася в окремий лінгвістичний розділ - ономастику”. Зазначений учений уважає, що „це засвідчує якусь особливу ономастичну специфіку, яка вимагає особливих підходів"”.

У наукову галузь українська ономастика виділилася на початку 60 -х років $\mathrm{XX} \mathrm{cT}^{10}$. В. Лучик нагадує, що поштовхом для іiї становлення й розвитку став заклик Л. Булаховського до українських мовознавців приділити належну увагу вивченню власних назв і проведення 1959 року I Республіканської ономастичної наради в Києві ${ }^{11}$.Серед основних напрямів ономастики поступово виокремили описову ономастику, ономастичну компаративістику, типологічну ономастику, соціолінгвістичну ономастику й літературну ономастику, хоч, як зазначає вищеназваний дослідник, зароджувалися й нові напрями, започатковані саме в Одеській ономастичній школі ${ }^{12}$.

Первісно ономастика містила лише одну дисципліну - антропоніміку ${ }^{13}$. На думку А. Зубко, „ономастика (від грецкого опота - ім'я, назва) - спеціальна історична дисципліна, що вивчає власні імена, їхнє функціонування в мові і суспільстві, закономірності їхнього утворення, розвитку й постійних перетворень” ${ }^{14}$. Цей учений зазначає, що „кожен онім - власна назва — містить інформацію про особливості іменованого об'єкту, у якій виникла назва, етнос, котрий створив назву, мову, на якій створена назва, і багато іншого"15.

На думку Ю. Карпенка, „ономастика — це розділ мовознавства, який досліджує власні назви, їхню сутність, специфіку, будову, групування, закономірності функціонування, їхнє походження та розвиток"16. Утім, цей учений наголошує, що $€$ підстави розмірковувати й про ономастику як про окрему науку, сурядну 3 мовознавством ${ }^{17}$. Науковець зауважує, що „ономастика дає багатющий матеріал для історії мови, історії народу, її даними користуються археологи, етнографи, географи та представники інших наук"18. Усі розряди власних назв містять ту чи ту інформацію, насамперед етнічну.

Українські дослідники сьогодні виокремлюють три етапи розвитку ономастики як наукової дисципліни ${ }^{19}$. Перший етап (тривав до сер. XIX ст.) охоплює

${ }^{6}$ В.В.Лучик, Актуальні напрями української ономастики, [в:] „Записки з ономастики”, 3б. наук. праць, відп. ред. Ю. О. Карпен ко, Одес. нац. ун-т ім. І. І. Мечникова, Одеса 2011, вип. 14, с. 126.

7 Там само.

${ }^{8}$ Ю.О.К Карпенко, зазнач. джер., с. 11.

${ }^{9}$ Там само.

${ }^{10}$ В. В. Лучик, зазнач. джер., с. 126.

${ }^{11}$ Там само.

${ }^{12}$ Там само

${ }^{13}$ А. М. Зубко, Украӥнська ономастика: здобутки та проблеми, [в:] Спеиіальні історичні дисиипліни: питання теорії та методики, зб. наук. праць, відп. ред. Г. В . Боря к, НАН України, Ін-т історії України, Київ 2007, с. 264.

${ }^{14}$ Там само, с. 262.

${ }^{15}$ Там само.

${ }^{16}$ Ю.О.Карпенко, зазнач. джер., с. 11.

${ }^{17}$ Там само.

${ }^{18}$ Там само, с. 12.

${ }^{19}$ А. М. Зубко, зазнач. джер., с. 264. 
появу словників власних назв та наукових розвідок із цієї проблематики. Умовно цей етап називають доакадемічною добою. Наступний етап розпочався тоді, коли з'явилися академічні філологічні дослідження з ономастики. Він охоплює др. пол. XIX ст. і перш. пол. XX ст. Третій етап триває від др. пол. XX ст. до поч. XXI ст., тобто до сьогодні. На цьому етапі дослідження з ономастики здійснюють як філологи, так й історики.

Дещо інший підхід до періодизації ономастичних досліджень можна знайти в енциклопедії слов'янської ономастики, що проектується саме на українську ономастику ${ }^{20}$. За цією класифікацією перший етап триває від др. пол. XIX ст. до перш. пол. XX ст. Тоді ономастику вивчали та використовували у зв'язку з дослідженням мови та історії українського народу. Другий етап охоплює повоєнні роки (1946-1958), коли ономастика стає галуззю мовознавства й окремим розділом етимології та лексикології. У цей період стверджується „розширення наукової проблематики, становлення теорії, методології і методики досліджень” ${ }^{21}$. Уважається, що „поворотним моментом у розвитку української ономастики став 1959 р. (поч. III етапу), коли в Києві відбулася I Республіканська ономастична нарада"22. 1960 року створюється Українська ономастична комісія. Вона започаткувала регулярне проведення Республіканської ономастичної наради.

Укажемо також на два підходи у вивченні онімів, що простежуються в наукових дослідження ${ }^{23}$. Перший з них об'єднав дослідників, які вважали ономастику спеціальною історичною дисципліною, що використовує власні назви як історичне джерело, а другий об'єднав учених-філологів, які використовують оніми як об'єкт у дослідженнях з історії мови та вважають ономастику частиною лінгвістики. Таким чином, дослідження власних назв здійснюють у кількох аспектах — вивчення їхнього змістового наповнення, його пояснення, що є завданням історичної науки, та опис їхньої лексичної форми і прагматики (цим займається власне лінгвістика).

Однак і в мовознавстві сьогодні власні назви вивчають у різних аспектах. Дослідники виокремлюють такі ономастичні галузі:

- описова ономастика - це фундамент усіх ономастичних досліджень, оскільки вона займається збиранням, аналізом онімів, зокрема вивченням їхньої будови й функцій та інтерпретацією зібраного матеріалу;

- теоретична ономастика досліджує загальні закономірності розвитку й функціонування системи власних назв;

- прикладна ономастика скерована на вивчення функціонування онімів в щоденному та офіційно-діловому мовленні;

- літературна ономастика студіює специфіку поширеності власних назв у художніх текстах;

- історична ономастика фокусує увагу на історичному розвитку власних назв та їхні зв'язки з реаліями різних епох і регіонів.

Ю. Карпенко стверджує, що „усі напрямки сучасного вивчення власних назв, тобто ономастика теоретична, описова, історична, прикладна, літературна, знаходяться на піднесенні, активно розвиваються й одержують нові здобутки" 24 .

20 Stowiańska onomastyka, Encyklopedia, $\mathrm{w} 2$ t., red. nauk. E. Rzetelska-Feleszko i A. Cieślikowa przy współpracy J. Dumy, Warszawa-Kraków 2002, t. 1, s. 16.

${ }^{21}$ Там само.

${ }^{22}$ Там само.

${ }^{23}$ А. М. Зубко, зазнач. джер., с. 263.

${ }^{24}$ Ю. О. Карпенко, зазнач. джер., с. 16. 
Цей дослідник наголошує, що „мало в якій галузі мовознавства стільки нелегких завдань і стільки невиконаної роботи, як в ономастиці”25.

Ядром української академічної ономастики вважається відділ ономастики Інституту української мови НАН України, у якому, як зауважує С. Вербич, зосереджена відповідно основна емпірична й теоретична база української ономастики ${ }^{26}$. Зазначений дослідник пише, що „це ядро не може повноцінно функціонувати без нормальної діяльності регіональних ономастичних центрів, які повинні виконувати функцію своєрідних кровоносних судин єдиного ономастичного організму"27.

Сьогодні в Україні функціонують три провідні ономастичні школи, а саме: Одеська, Донецька, Ужгородська. Усі із зазначених ономастичних шкіл докладно вивчають специфіку функціонування онімів у художньому стилі мовлення ${ }^{28}$. Зазначимо, що кожен з вищезгаданих ономастичних осередків зробив чималий внесок у розробку ономастичної теорії.

Одеську ономастичну школу заснував і очолював понад сорок років Ю. Карпенко - український мовознавець, член-кореспондент НАН України, фундатор літературної ономастики в Україні. Серед представників Одеської ономастичної школи, крім Ю. Карпенка, виокремимо М. Зубова, О. Карпенко, Т. Крупеньову, Л. Фоміна.

Одеський ономастичний осередок видає фаховий збірник наукових праць „Записки з ономастики”. Дослідники цієї школи займаються передусім студіюванням питань літературної та когнітивної ономастики ${ }^{29}$, що пов'язано 3 аналізом онімів як ментальних концептів, елементів мовної картини світу українців ${ }^{30}$.

Представниками Донецької ономастичної школи є В. Калінкін, Е. Кравченко, Г. Лукаш, С. Отін, О. Філатова та ін. Працівники цього наукового осередка розробляють сучасні підходи до аналізу походження, історії, функціонування, лексикографування онімів у російській та українській мовах ${ }^{31}$.

Є. Отін як засновник цієї ономастичної школи послуговувався порівняльноісторичним методом вивчення власних назв, що є ефективним для відновлення, реконструкції генетичних зв'язків цього лексичного пласту ${ }^{32}$. Названий дослідник ретельно вивчав походження та історію власних назв, кваліфіковано лексикографував цей матеріал ${ }^{33}$. Д. Дергач зауважив, що історико-порівняльний метод в ономастиці, який активно застосовував власне $Є$. Отін в проекції на російську та українську мови, „передбачає вивчення матеріалу в його історичній перспективі, яка допомагає простежити поступову і послідовну зміни одного

${ }^{25}$ Там само, с. 17.

${ }^{26}$ С. Вербич, Українська ономастика: перспективи розвитку, [в:] „Українська мова”, Київ 2010, № 3, с. 77.

${ }^{27}$ Там само.

28 I. В. Тільнова, Особливості переносного вживання топонімів у засобах масової інформації, [в:] „Система і структура східнослов'янських мов”, зб. наук. праць, редкол. В. П. Андру щен ко та ін., Нац. пед. ун-т ім. М. П. Драгоманова, Київ 2012, вип. 6, с. 57.

${ }^{29}$ Див.: О.Ю.Карп ен ко, Проблематика когнітивної ономастики, Одеса 2006.

30 Д. В. Дерг ач, Реферат циклу наукових прачь „, Оніми в літературній мові украйнського народу”, [в:] Електронний ресурс: www.kdpu-nt.gov.ua/sites/default/files/m46.doc, c. 3-4 (12.02.2017).

${ }^{31}$ Там само, с. 3.

32 Д. В. Дергач, Тендениії дослідження власних назв: від традииії до сучасності, [в:] „Актуальні проблеми української лінгвістики: теорія і практика”, зб. наук. праць, гол. ред. Л. І. Шевченко, Київ 2008, вип. 16, с. 101.

${ }^{33}$ Там само. 
й того ж елемента чи ряду взаємопов'язаних складових частин і виключає випадковість і ненауковість етимологічного дослідження" 34 .

Крім того, досягненням Є. Отіна й Донецької ономастичної школи загалом стала теорія конотонімів і відповідний словник для фіксації й опису зазначений мовних одиниць російської мови ${ }^{35}$.

На українському мовному матеріалі цю проблему почала активно й успішно досліджувати учениця $€$. Отіна Г. Лукаш ${ }^{36}$. Розробляючи теорію літературної ономастики, В. Калінкін ${ }^{37}$ запропонував нові терміни, зокрема й для назви цього напряму ономастики, - поетика оніма, або поетонімологія ${ }^{38}$. Донецька ономастична школа видає авторитетний науковий журнал „Ономастичні науки”.

Ужгородську ономастичну школу очолює П. Чучка (закарпатська антропонімія), репрезентують іiі, між іншими, Л. Белей ${ }^{39}$ (літературна антропонімія), С. Пахомова (слов'янська антропонімія), М. Сюсько (зоонімія) ${ }^{40}$, О. Белей (ергонімія $\left.{ }^{41}\right)$. Представники згаданої школи на позначення науки, що досліджує функціонування власних назв у художньому тексті, запропонували термін літературно-художня ономастика (Л. Белей), хоч Л. Белей займається дослідженням власних назв у широкому ракурсі ${ }^{42}$.

Деякі дослідники виділяють також Київську ономастичну школу, що сформована насамперед відділом ономастики Інституту української мови НАН України та посилена ономастами Києво-Могилянської академії й Київського національного університету ім. Т. Г. Шевченка ${ }^{43}$. У цьому філологічному осередку видають журнал „Студії з ономастики та етимології”. Представники цієї школи, зокрема С. Вербич, І. Желєзняк, В. Лучик, В. Шульгач, займаються переважно (деякі виключно) історико-етимологічною ономастикою, передусім дослідженням топоніміки ${ }^{44}$. Представник Київського філологічного кола ономастів А. Білецький, як і Є. Отін, є прихильником порівняльно-історичного методу. Свою увагу цей дослідник фокусував на індивідуальну чи групову історію онімів ${ }^{45}$. Д. Дергач наголошує, що „використання такого прийому допомагало вченому зорієнтуватися в напрямках і методах своїх студій, віднайти точки дотику, спільні і відмінні риси досліджуваного матеріалу"46. А. Білецький

${ }^{34}$ Там само, с. 3

${ }^{35}$ Е. С. Отин, Словарь коннотативных собственных имен, 3-е изд., перераб. и доп., Донецк 2010.

${ }^{36}$ Г. П. Лукаш, Актуальні питання украӥнської конотоніміки, Донецьк 2011.

${ }^{37}$ В. М.К Калин и ин, Поэтика онима, Донецк 1999.

38 Див. про це: Ю. О. Карпенко, Л. Ф. Фоміна, М. І. Зубов, В. М. Калінкін, Одеська ономастична школа, [в:] „Ономастичні науки”, зб. наук. праць, гол. ред. С. С. Отін, Донецьк 2012, № 4, с. 109.

39 Див.: Л. Белей, Функиіонально-стилістичні можливості української літературнохудожньої антропонімії XIX-XX cm., Ужгород 1995; Л. Белей, Українська літературнохудожня антропонімія кіния XVIII-XX cm., автореф. дис. ... д-ра. філол. наук, Ужгород 1997; Л. Белей, Нова украйнська літературно-художня антропонімія: Проблеми теорії та історії, Ужгород 2002.

40 Див. про це: Ю. О. Карпенко, Л. Ф. Фоміна, М. І. Зубов, В. М. Калінкін, зазнач. джер., с. 110.

${ }^{41}$ О. О. Белей, Сучасна украӥнська ергонімія: власні назви підприємтв Закарпаття, Ужгород 1999.

42 Л. Беле й, Українські імена колись і тепер, Київ 2010.

${ }^{43}$ Ю. О. Карпенко, Л. Ф. Фоміна, М. І. Зубов, В. М. Калінкін, зазнач. джер., с. 109.

${ }^{44}$ Там само, с. $109-110$.

${ }^{45}$ Д.В.Дергач, Тендениї̈ дослідження власних назв: від традищї до сучасності..., с. 102.

${ }^{46}$ Там само. 
використовує також формальний метод, постулати якого проектує передусім на опозицію власних і загальних назв ${ }^{47}$.

На вивченні історико-етимологічної ономастики 3 переважною увагою на топоніміці сконцентрована Чернівецька ономастична школа (Н. Колесник, Я. Редьква, О. Юдін).

Тернопільський ономастичний осередок репрезентований передусім солідними працями і Г. Бучко і Д. Бучка ${ }^{48}$, а також С. Панцьо. Д. Бучко проектував роботу на топоніміку України, входив до авторського міжнародного колективу з укладання Слов'янського ономастичного атласу, робота над яким розпочалася ще 1958 року відповідно до рішення IV Міжнародного з'їзду славістів (м. Москва).

Історико-етимологічний напрям характерний також для Ужгородської ономастичної школи, але 3 проекцією на антропонімію ${ }^{49}$.

До Львівської ономастичної школи входять такі вчені, як І. Фаріон і М. Худаш, які продовжують ономастичні традиції Л. Гумецької та Ю. Редька ${ }^{50}$. Їхні досліджнення спрямовані на антропонімію в її історико-етимологічному осмисленні ${ }^{51}$.

Українські ономасти постійно приділяють увагу проблемі метамови, що стосується передусім типології власних назв, наприклад, В. Німчук (Київська ономастична школа) пропонує класифікацію онімів 3 поділом на: 1) власні назви місць (топоніми); 2) інші власні назви (назви установ, свят, літературних творів тощо); 3 ) живі істоти ${ }^{52}$. М. Торчинський (Кам'янець-Подільський) розробив ієрархію власних назв 3 поділом на поля, підполя, сектори, підсектори, сегменти, підсегменти, елементи та піделементи ${ }^{53}$.

У результаті аналізу інформаційного наповнення онімів О. Карпенко (Одеська ономастична школа) пропонує підхід до профілювання (появу нового онімічного концепту) і побудови онімічних фреймів ${ }^{54}$. М. Торчинський зауважує, що „критерії, на основі яких структурується онімний простір, — це сукупність досить різнопланових ознак пропріальних одиниць, серед яких виокремлюються як загальномовні особливості, так і диференційні, специфічні саме для власних назв" 55 . Цей дослідник виокремлює основні критерії структурування онімого простору, що, на його думку, забезпечують створення стрункої, логічної, послідовної типології онімів:

1) характер іменованих об'єктів;

2) особливості творення власних назв (не лише власне спосіб творення пропріативів, а також семантика твірних основ, мотиваційні відношення між денотатом й онімом, продуктивність словотвірного типу, етимологія, походження, час і шлях виникнення та структура онімних одиниць;

\footnotetext{
${ }^{47}$ Там само

48 Див., напр.: Г. Бучко, Д. Бучко, Історична та сучасна українська ономастика: Вибр. праиі, Чернівці 2013.

${ }^{49}$ Ю. О. Карпенко, Л. Ф. Фоміна, М. І. Зубов, В. М. Калінкін, зазнач. джер., с. 110.

${ }^{50}$ Там само.

${ }^{51}$ Там само.

${ }^{2}$ Ю. В. Гл юдз и к, Лінгвокультурологічні особливості поетонімії К. С. Льюїса „, The Chronicles of Narnia", Ужгород 2015, c. 14.

${ }_{53}$ М. М. Торч и н с к ий, Денотатно-номінативна структура оронімії як складник української ономастичної терміносистеми, [в:] „Наук. праці Кам’ян.-Поділ. нац. ун-ту ім. Івана Огієнка, сер. Філологічні науки", зб. наук. праць, відп. ред. О.В.Ке ба, Кам’янець-Подільський 2010 , вип. 23 , с. 261.

${ }^{54}$ Ю. В. Глюдзик, зазнач. джер., с. 16-17.

${ }^{55}$ М. Торч и н сь к й й, Онімна система і критерії ї̈ аналізу, [в:] Електронний ресурс: http:// dspace.tnpu.edu.ua/handle/123456789/6493, c. 284 (15.03.2017).
} 
3) функціонування пропріативів (ураховуються стилістичні особливості власних назв, сфера і форма їхнього уживання, а також кодифікаційні ознаки, зокрема правопис і відмінювання $)^{56}$.

Доробок основних українських ономастичних шкіл доповнюється окремими розвідками науковців поза названими школами (Т. Космеда ${ }^{57}$, Н. Щербакова $^{58}$ та ін.).

Над узагальненням ономастичної термінології постійно працює чимало мовознавців, зокрема великим досягненням сучасної української ономастики став словник ономастичної термінології, укладачами якого $є$ Д. Бучко і Н. Ткачова $(2012)^{59}$.

До розробки української ономастичної лексикографії долучилися представники всіх ономастичних шкіл (див. словники власних імен людей ${ }^{60}$, зокрема й псевдонімів ${ }^{61}$, словники географічних назв ${ }^{62}$ ).

${ }^{56}$ Там само, с. 285.

57 Див.: Т. Ко смеда, Аксіологічні аспекти прагмалінгвістики: формування і розвиток категорії оцінки, Львів 2000; Т. А. Космеда, Ego i Alter Ego Tapaca Шевченка в комунікативному просторі щоденникового дискурсу, Дрогобич 2012; Т. А. Космеда, Н. В. Піддубна, Т. Ф. Осіпова, Степан Руданський: феномен моделювання “живого” мовлення україниів, Познань-Харків-Дрогобич 2015 та ін.

${ }^{58}$ Н. В. Щербакова, Псевдоніми сучасних украӥнських митців в аспекті етнокультури, [в:] „Лінгвістичні дослідження” зб. наук. праць ХНПУ ім. Г. С. Сковороди, наук. ред. Л. А. Лисиченко, Харків 2011, вип. 32; Н. В. Щербакова, Псевдонім для віртуальної особистості, [в:] „Психолінгвістика”, зб. наук. праць ДВНЗ Переяслав-Хмельн. держ. пед. ун-т ім. Григорія Сковороди, наук. ред. Л.О.К Калмико ва, Переяслав-Хмельницький 2009, вип. 3; Н. В.Щерббакова, Про соиіальні аспекти псевдонімної номінації, [в:] „Лінгвістичні дослідження", зб. наук. праць ХНПУ ім. Г. С. Сковороди, наук. ред. Л.А.Ли с и че н ко, Харків 2015, вип. 40.

${ }^{59}$ Див.: Словник української ономастичної термінологї, уклад. Д. Г. Бучко, Н. В. Ткачова, Харків 2012.

${ }^{60}$ Див.: Власні іменалюдей, слов.-довід., уклад. Л. Г. Скрипник, Н. П. Дзя тків ська, ред. В. М. Русанівський, НАН України, Ін-т мовознав. ім. О. О. Потебні, 2-е вид., випр. й допов., Київ 1996; Довідник украӥнських прізвищ, уклад. Ю.К.Р едько, ред. І.В арченко, Київ 1968; Правописний словник імен і найпоширеніших прізвищ, уклад. А. А. Бурячок, УАН нац. прогр., Ін-т гуманіт. досл., Київ 1996; Прізвища степової України: Словник, уклад. В. О. Гор п и н и , Дніпропетровськ 2000; Украӥнські прізвищеві назви Прикарпатської Львівшчни наприкіниі XVIII - початку XIX століття (з етимологічним словником), уклад. I. Д. Фарі о н, НАН України, Ін-т народозн., Львів 2001; Словник прізвищ: практичний словозмінно-орфографічний (на матеріалі Чернівеччини), уклад. Н. Д. Бабич та ін., голов. ред. К. М. Лук'я нчук, Чернівці 2002; П. П. Чучка, Прізвища закарпатських украӥнців: Історико-етимологічний словник, Львів 2005; I. Тр ійн я к, Словник украӥнських імен, Київ 2005.

61 Див.: О. Тулуб, Словник псевдонімів українських письменників: Матеріали, Київ 1928; О. І. Дей, Словник українських псевдонімів та криптонімів (XVI-XX ст.), Київ 1969; В. Е ппе ль, Нові матеріали до словника українських псевдонімів, Київ 1999.

62 Див.: Каталог річок України, уклад. Г. І. Шве ць, Н.І.Дрозд, С. П. Левченко, Київ 1957; Ю. М. Кругл я к, Ім'я вашого міста: Походження назв міст і селищ міського типу Української РСР, Київ 1978; Словник гідронімів України, уклад. І.М.Желєзн я к, А.П.Кор еп ан о ва та ін., АН УРСР, Ін-т мовозн. ім. О. О. Потебні, Київ 1979; Етимологічний словник літописних географічних назв Південної Русі, уклад. І. М. Желєз н як та ін., АН УРСР, Ін-т мовозн. ім. О. О. Потебні, Київ 1985; В. О.Гор п ин и ч, Словник відтопонімічних прикметників $i$ назв жителів України, у 2 томах, Кіровоград 1994; М. Л. Худа ш, Украӥнські карпатські і прикарпатські назви населених пунктів. Утворення від слов'янських автохтонних відкомпозитивних скорочених особових власних імен, НАН України, Ін-т народозн., Київ 1995; М. Т. Ян ко, Топонімічний словник Украӥни: Словник-довідник, Київ 1998; К. М. Т ищен ко, Іншомовні топоніми Украӥни: Етимологічний словник-посібник, Тернопіль 2010; В.В.Лучи к, Етимологічний словник топонімів України, Київ 2014. 
Утім, українська ономастика має великі перспективи й чималий потенціал розвитку, оскільки українські ономасти репрезентують новаторські підходи до вивчення ономастики, насамперед когнітивної, літературної, поетичної та лексикографічної, увага зосереджується й на вивченні прагматики власної назви. 